\title{
Evaluation research in occupational health services: general principles and a systematic review of empirical studies
}

Carel T J Hulshof, Jos H A M Verbeek, Frank J H van Dijk, Willeke E van der Weide, Ingrid $\mathrm{T} \mathrm{J}$ Braam

\begin{abstract}
Objectives-To study the nature and extent of evaluation research in occupational health services (OHSs)

Methods-Literature review of evaluation research in OHSs. On the basis of a conceptual model of OHS evaluation, empirical studies are categorised into aspects of input, process, output, outcome, and OHS core activities.

Results-Many methods to evaluate OHSs or OHS activities exist, depending on the objective and object of evaluation. The amount of empirical studies on evaluation of OHSs or OHS activities that met the non-restrictive inclusion criteria, was remarkably limited. Most of the 52 studies were more descriptive than evaluative. The methodological quality of most studies was not high. A differentiated picture of the evidence of effectiveness of OHSs arises. Occupational health consultations and occupational rehabilitation are hardly studied despite much time spent on the consultation by occupational physicians in most countries. The lack of effectiveness and efficiency of the pre-employment examination should lead to its abandonment as a means of selection of personnel by OHSs. Periodic health monitoring or surveillance, and education on occupational health hazards can be carried out with reasonable process quality. Identification and evaluation of occupational health hazards by a workplace survey can be done with a high output quality, which, however, does not guarantee a favourable outcome.

Conclusions-Although rigorous study designs are not always applicable or feasible in daily practice, much more effort should be directed at the scientific evaluation of OHSs and OHS instruments. To develop evidence-based occupational health care the quality of evaluation studies should be improved. In particular, process and outcome of consultation and rehabilitation activities of occupational physicians need to be studied more. (Occup Environ Med 1999;56:361-377)
\end{abstract}

Keywords: review; occupational health services; evaluation of research

Health services research

As $45 \%$ of the world's population belong to the workforce, occupational injuries and work related diseases have an important impact on health. Other diseases, although not primarily caused by work, may influence the working ability. Occupational health services (OHSs) are supposed to play an important part in prevention and control of occupational diseases and injuries and in occupational rehabilitation. In the World Health Organisation (WHO) global strategy for "occupational health for all", governments are asked to prepare actions for providing competent OHSs for all people at work and for effective implementation of OHSs. ${ }^{1}$ The terms competent and effective assume knowledge on the required quality of health care provided by these services. What do we know about this? Scientific evaluation of health care is part of health services research. Health services research in general seeks to analyse the functions and objectives of health services, including the political, social, and economic forces shaping and conditioning the funding, organisation, management, priorities, efficiency, and effectiveness of the services. ${ }^{2}$ Due to the demand for effectiveness of care, for decision making in health programmes, for the development of standards and guidelines, and for the need for cost containment, health services research has become much more prominent in recent years. ${ }^{3}$ Epstein refers to "the outcomes movement: the third revolution in medical care". "This development seems not yet to be reflected in the field of occupational health. There was a lack of published empirical studies on the work in OHSs. ${ }^{56}$ In past years, similar developments in occupational health care can be identified to those in general health care: budget cuts, market competition, and decrease or withdrawal of governmental grants. Because of the specific setting of occupational health care in social and economic life, there is an increasing demand for justification of the effectiveness and efficiency of OHSs from outside the profession: employers, branches of economic activity, governments, trade unions, scientists, and insurance companies. Behrens et 
al refer to "the path breaking function of evaluation research". ${ }^{7}$ Concerns about quality of care, cost, and unnecessary medical care have also emerged in occupational health care. ${ }^{8}$ All this can be seen as the need for external evaluation. ${ }^{9}$ There is also a need for internal evaluation. New developments in working life and the work environment, and demographic changes in working populations call for new strategies and programmes. Changing legislation and professional and scientific interest in the quality of occupational health care can also form a stimulus for studying aspects of quality in OHSs. ${ }^{10}$ In 1982, a WHO working group recommended that the evaluation of OHSs should be a regular activity, fully integrated into the planning and implementation of occupational health and safety programmes. ${ }^{11} \mathrm{How}-$ ever, despite a rich history of aetiological research, the field of occupational health and safety does not have a long history of research on what works and what does not work to prevent and control occupational diseases and injuries. ${ }^{12}$ Also in the field of occupational rehabilitation in cases of sickness absence or disability, a considerable lack in scientific knowledge on effective and efficient strategies exists. The need has arisen for studies on the effectiveness of prevention strategies, programmes, and services. Skov and Kristensen distinguish between aetiological intervention studies seeking causes of diseases, and prevention effectiveness studies evaluating the effectiveness of methods for prevention, ${ }^{13}$ which is often inspired or conducted by principles and methods in use in evaluation research.

Although the term evaluation research is commonly used, there is no single or clear cut definition of it. Depending on the context or the scientific field in which the research is conducted, various research activities can be categorised under this heading. From social science publications, clinical or epidemiological research, and quality assurance, different concepts and types of evaluation research can be derived. Notwithstanding this difference in scientific origin and terminology, many analogies and overlap between these concepts exist.

\section{Objective}

The purpose of this paper is to review the nature and extent of evaluation research in OHSs. We studied the scientific literature for some general principles and methodological aspects of evaluation research in occupational health care and we reviewed the empirical studies in this field. The main question of this review is almost a rhetorical one: how well are we doing? What is known of input, process, and outcome of occupational health care as it is provided by OHSs?

In this paper, we focus on evaluation of the activities of OHSs. This is excluding a considerable amount of prevention effectiveness research in the field of occupational health. Research on non-OHS related interventions, programmes, and policies to reduce workplace health hazards and public health oriented research on health promotion at the work site-for example, hypertension control, em- ployee assistance programmes on drugs, alcohol, or fitness - are not represented in this review. In these areas, several comprehensive reviews have been published. Goldenhar and Schulte reviewed the intervention studies in the field of occupational health and safety published between 1988 and 1993, and concluded that in particular the number and methodological rigor of intervention studies has to be increased to identify effective intervention methods. ${ }^{14}$ To contribute to the development of practice guidelines for occupational physicians, van der Weide et al assessed the level of evidence of the efficacy of non-surgical interventions for workers with low back pain. Vocational status was a measure of outcome and they concluded that the scientific evidence for the efficacy of interventions for patients with low back pain in decreasing rates of sickness absence or duration of sick leave is limited..$^{15}$ In a review on economic implications of programmes that promote health in the workplace, Warner et al raised doubts on the evidence of cost effectiveness of many of these programmes. ${ }^{16}$ In another review on health and cost effective outcome of promotion of health at the workplace and disease prevention programmes, Pelletier was more optimistic: all of the 24 studies included indicated positive health benefits or positive cost effects. ${ }^{17}$ An update of this review in 1993 confirmed these findings and also reported an important improvement of research design, data analysis, and complexity of interventions. ${ }^{18}$ For the field of occupational health and safety in general, the findings of these reviews in both areas provide important information. However, for evaluating the practice of occupational health care, the information is limited. At best, they offer an indication of the efficacy of treatments or interventions in a well controlled and often more or less artificial situation. Black recently called attention to the fact that most randomised trials are explanatory - that is, they provide evidence of what can be achieved in the most favourable circumstances. ${ }^{19}$ They often do not deal with effectiveness in health care in everyday practice. In this review, emphasis is on process and outcome of occupational health care as it is provided in its typical everyday practice setting: the OHS.

\section{Methods}

SELECTION OF THE PUBLICATIONS

For the publications on general principles and methodological aspects of evaluation research in occupational health care, we used a few essential handbooks and monographs and collected additional scientific literature by checking citations in relevant publications and by a computerised search in Medline. The available publications on empirical studies in OHSs were selected in an automatic search of the computerised databases Medline, OSH-ROM, CIS-DOC, HSE-line, Embase, and Current Contents. Also, the references in relevant articles and in background literature were further examined. For computer searches we used the following keywords: effectiveness, evaluation study, health services research, occupational 
health services, outcomes research, outcome assessment, outcome evaluation, outcome and process assessment, process evaluation, programme evaluation, pre-employment examination, periodic occupational health examination, occupational rehabilitation, medical consultation, audit, quality, and practice guidelines.

The empirical studies had to meet the following inclusion criteria:

(1) The study had to deal specifically with evaluation of OHSs or OHS instruments. The OHS instruments (defined as circumscript and formalised working methods and measurement protocols, inclusive equipment, and strategies ${ }^{10}$ ) were restricted to workplace investigations and evaluation on work related hazards; management consultation; information and education of employees on work related hazards; pre-employment examination; periodic occupational health examination or surveillance; consulting hours; occupational rehabilitation, and first aid organisation.

(2) The paper had to present original study results; reviews were excluded.

(3) The study was published in English in an international (peer reviewed) journal.

(4) The work was published between 1985 and 1996.

In particular, the third criterion excluded many evaluation studies. Most evaluation research actually carried out in OHSs goes unpublished or is published in reports in the "grey literature", often exclusively directed at financial suppliers, programme funders, or decision makers. We insisted on this because we think that dissemination of research findings in the scientific and professional field is an essential prerequisite. ${ }^{20}$

\section{QUALITY ASSESSMENT}

Quality assessments in a review can be used as a threshold for inclusion, as a possible explanation for differences in results between studies, in sensitivity analyses, and as weights in statistical analysis or meta-analysis of the results. ${ }^{21}$ In systematic reviews on the efficacy of a specific intervention, often there is an exclusion of studies with a lower methodological quality or studies are rated to see if they meet some minimum (particularly methodological) quality criteria. In this review, we chose not to use a quality assessment procedure for inclusion or weighting of studies. Because of the broad focus of this review (the nature and extent of evaluation research in OHSs) and consequently, the heterogeneity of the studies and study objects, it is very difficult to adopt a quality rating system applicable to the different types of studies in OHSs.

\section{PRESENTATION OF PUBLICATIONS}

In the first part of this paper, we highlight some general principles and methodological aspects and present a conceptual model for evaluation of OHSs. This model is used in the second part of the paper to present the empirical studies. We used the conclusions of the authors to report positive or negative findings. If authors did not formulate a concrete finding or studies were more descriptive in nature, the results are reported as indefinite.

\section{Results}

EVALUATION RESEARCH IN HEALTH CARE;

GENERAL PRINCIPLES

Terminology

The history of evaluation research is linked to the growth and standing of the social sciences, in particular to the evaluation of educational programmes, and to the assessment of public health initiatives to reduce morbidity and mortality from infectious diseases. ${ }^{12}$ Evaluation of health care is defined as "the assessment of effectiveness, efficiency, acceptability, and acceptance of a care system or programme in achieving the stated objectives". ${ }^{11}{ }^{22}$ According to this definition, evaluation research is closely related to intervention research: "the study of planned and applied activities designed to produce designated outcomes"14 and to outcomes research: "study of health care received by typical patients with a particular condition to a range of positive and negative outcomes to identify what works best and for whom". ${ }^{8}$ Effectiveness of health care is a measure of technical outcome, in terms of health. Efficiency is an economic concept referring to the costs of the care system or programme relative to its effectiveness. Acceptability refers to whether the care is professionally and socially satisfactory and adequate. Acceptance can be defined as the psychosocial process (individually or collectively) of accepting health care. ${ }^{22}$

The study objects of evaluation research in health care can be classified in different ways. According to Donabedian most of these classifications distinguish input (or structure), process, and outcome aspects of health care. ${ }^{23}$ Input or structure aspects can be divided into "system characteristics" (administrative, organisational, physical, and financial facilities), "provider characteristics" (knowledge, specialty training, beliefs, and attitudes), and "patient or client characteristics" (age, sex, health habits, preferences, expectations). Process refers to the content of the provided care; technical aspects (activities, continuity of care, etc) and treatment aspects like interpersonal manner and communication style. Outcome deals with the effects of the care on the health of patients or populations. In its most basic form, the outcome of health care can be classified under the "five ds": death, disease, disability, discomfort, and dissatisfaction. ${ }^{22}$ Recent developments in health services research show the use of other and broader outcome variables such as functional, general wellbeing, satisfaction with care, quality of (working) life, knowledge, skills, and behaviour outcomes.

Outcome evaluation: aspects of study design Outcome evaluation requires an explicit research design. The most important elements in selecting a design are: the use of comparison or control groups (truly experimental, quasiexperimental, or non-experimental) and the timing of measures: pretest-post-test, post-test only, or time series. ${ }^{24}$ The most rigorous evaluation design is the true experimental 
pretest-post-test control group design. ${ }^{25}{ }^{26}$ In clinical research, this design is better known as a randomised controlled trial (table 1). It is regarded as the "gold standard" in clinical outcome research, especially because of its high internal validity. However, when evaluating effectiveness of health care, this may be disputed. In particular, the low external validity of many randomised controlled trials may cause problems by offering an indication of the theoretical efficacy of an intervention rather than its effectiveness in everyday practice. ${ }^{19}$ This also holds true for evaluation research in occupational health care. In this field, often the applicability of such a rigorous research design is limited. In particular, in activities of OHSs directed to groups (improvement of working conditions or an educational programme) randomisation at the individual level is not possible. This problem may sometimes be solved by randomisation at the population level-for example, plant or department - but this requires very large sample sizes, often not feasible. In such cases, researchers have to rely on a less rigorous design. Also ethical or legal matters in occupational health care can interfere with the use of a true experimental design. Therefore, in health services research, quasiexperimental study designs are often chosen. Such designs, also called non-equivalent pretest-post-test designs, make use of control groups not selected by random assignment but by techniques of matching, stratification, etc. ${ }^{25}$ In studies evaluating OHSs, researchers will often assign factories or factory departments to experimental and control groups.

A non-experimental evaluation design (also known as single group design) includes an experimental group only. No control group is used in its most basic form: the one group post-test only design. From this design, one cannot easily infer that the treatment is related to any kind of change. ${ }^{26}$ More often a design is used in which the target populations act as their own control, often on a before-after comparison basis: the one group pretest-post-test design. Although widely used, the validity of such a design is limited. A possibility for strenghtening of this design is to increase the number of observations before and after the intervention. Such a time series design ideally includes at least three measurements before and three after the intervention has taken place. The changes in trends must be consistent for the different groups but the same intervention must have been introduced at different times. ${ }^{27}$ A different category is formed by the judgemental designs. In this design, no objective measurements are made, but experts, programme staff, participants, or other parties involved, assess the outcome of the programme. ${ }^{28}$

Process evaluation

Process evaluation is the evaluation of the various components of the health care provided. Process evaluation involves making judgements about how well a programme operates. ${ }^{22}$ Two basic questions of process evaluation are: does the intervention reach the target group and was the intervention carried out in the way it was planned? ${ }^{29}$ A scale of different measurement methods can be used in process evaluation: questionnaire surveys-for example, testing knowledge or attitudes before and after a health education programme-analysis of registered activities, direct observation, measurement of use, audit, etc.

Process evaluation may sometimes be regarded as a proxy measure for judging outcome but it remains difficult to show cause and effect between process used and outcome achieved. ${ }^{30}$ The worth of process evaluation should not be underestimated. For new health programmes, knowledge of how a succesful or an unsuccesful outcome was obtained, will have the most impact on future decision making. ${ }^{31}$ Especially, when outcome findings are negative, a thorough process evaluation can provide information on the reason for this negative outcome; is it a lack of implementation or a lack of efficacy of the service or programme? Compliance with health programme components is always an important factor in intervention studies. ${ }^{32}$ As a part of process evaluation, it is necessary to document the degree of compliance as much as possible. Measuring the process of care may in some circumstances be even more effective than measuring outcomes. Outcome studies often need to be run for several years to detect deficiencies in care. ${ }^{33}$ Sometimes, traditional outcome measures-for example, accidents in safety performance-are rare events in the statistical sense, and consequently, not sensitive enough to evaluate the effectiveness of specific intervention programmes. ${ }^{34}$ Process data may sometimes be more sensitive measures of quality than outcome data because a poor outcome does not occur every time there is an error in the provision of care. ${ }^{35}$ Therefore, in comprehensive evaluation studies, true or quasi-experimental designs for outcome measurements should be combined with process evaluation to monitor how this outcome was achieved. A similar distinction can be made between summative and formative evaluation. Summative evaluation has to give a judgement (in quantitative or statistical terms) of the value or outcome of a programme, mostly by an outside expert.

Table 1 Comparability and terminology of study designs in different scientific disciplines

\begin{tabular}{|c|c|c|c|}
\hline Rank order & Evaluation study (social sciences) & Clinical research/observational epidemiology & Quality assurance \\
\hline 1 & True experimental, pretest-post-test control group design & $\begin{array}{l}\text { Randomised controlled trial, community } \\
\text { intervention trial }\end{array}$ & \\
\hline 2 & Quasi-experimental design & Cohort study, case control study & \\
\hline 3 & Non-experimental design: eg time series & Patient series, descriptive study & \\
\hline \multirow[t]{2}{*}{4} & Judgemental design & & Peer review, audit, satisfaction with care \\
\hline & Process evaluation & Compliance, descriptive study & $\begin{array}{l}\text { Audit, certification, guidelines, } \\
\text { satisfaction }\end{array}$ \\
\hline
\end{tabular}


Formative evaluation is the systematic monitoring, often by a member of in house staff, of an ongoing programme or policy with the intention to control and improve the progress. ${ }^{36}$

Quality and audit

Another contribution to evaluation research in health care comes from quality control principles. A definition of quality of care is "the degree to which health services for individual subjects and populations increase the likelihood of desired health outcomes and are consistent with current professional knowledge". ${ }^{37}$ Also in the assessment of quality of care, the Donabedian structure, process, and outcome triad can be applied. Quality assurance is the process that ensures that the standards or level of quality which have been specified are met. This requires audit and measurement. Audit involves observing practice and comparing it with a standard. Realistic performance standards need to be set and performance indicators have to be developed. ${ }^{38}$ The most important critical success factor in this approach is to develop performance indicators and perform meaningful measurements.

\section{Practice guidelines}

In the quest for evidence-based medicine, the development of practice guidelines for health professionals is rapidly gaining popularity. Professionalisation, accountability, and efficiency are the most important reasons. ${ }^{39}$ The degree of implementation and use of professional standards or guidelines within OHSs may reflect a measure of quality of the care provided and may be subject to evaluation at the process level. Evidence of change in health outcomes due to the effectiveness of practice guidelines should be the subject of outcome evaluation. In a systematic review on the effect of clinical guidelines on medical practice, Grimshaw and Russel concluded that explicit guidelines do improve clinical practice. ${ }^{40}$ The impact of practice guidelines on quality of care is, however, often hampered by poor implementation. ${ }^{41}$

\section{Satisfaction}

The effectiveness of health care is not only determined by quality variables but also by the acceptance of the parties involved. Acceptance is closely associated with satisfaction of patients or populations with care. Some authors regarded satisfaction as a process measure, important as a means to gain acceptance of and participation in the service being provided. ${ }^{27}$ Others considered patient satisfaction to be one of the desired outcomes of care, even an element in health status itself. ${ }^{23}$

\section{MODELS AND METHODS IN OHS EVALUATION} RESEARCH

Evaluation objectives in OHSs

The formulation of clear objectives is a prerequisite for evaluation research. ${ }^{42}$ Therefore, it is important to know what can be considered as the primary goal of OHSs. The OHSs vary much in structure and function, more so than primary health care or hospital services, even in industrialised countries. ${ }^{43}$ In the United States, many occupational physicians and nurses are involved in general work site health promotion programmes. In 1985, the United States Public Health Service's national work site survey showed that $65 \%$ of work sites with $>50$ employees had at least one ongoing health promotion programme. ${ }^{44}$ In analysing this American phenomenon of health promotion programmes, Conrad distinguishes corporate factors-for example, the lack of a national health insurance system means that most of the companies pay for a large portion the general health bill-health factors (the emergence of the lifestyle risk factor paradigm in medicine) and cultural factors (an improved interest in jogging, fitness, and wellness). ${ }^{45} \mathrm{He}$ draws attention to the many pitfalls of this lifestyle approach, in particular to the danger of crossing the thin line from individual responsibility to blaming the victim. In some other countries, OHSs are also involved in curative health care. In Finland, employees use the OHS units instead of the municipal healthcare centres partly for general practitioners services. ${ }^{46}$ Therefore, the question "what is the goal of OHSs ?" may lead to different answers in different countries or even in different regions or companies within one country. Moreover, OHS professionals, OHS managers, employers, and employees may have different opinions about the goals of OHSs.

\section{OHS evaluation models}

In the scientific literature, a clear distinction is not always made between evaluation definitions, types of evaluation, and evaluation models. Menckel gives an overview of approaches to and models for evaluation of OHS activities. ${ }^{47}$ She presents a classification of some major evaluation models, the systems analysis model and the behavioural objectives model, being the most prominent ones. The aim of the systems analysis model is to provide an evaluation of an entire body of activities. It is always summative and is mostly initiated after a programme has been completed-for example, "can OHSs contribute to a reduction in occupational injuries?". The behavioural objectives model, commonly used in health education programmes, is more formative in nature. It evaluates the effects of a specific measure taken-for example, "have back exercises led to improved physical fitness?". Process criteria are important and OHS personnel may be involved more directly in this type of evaluation. In general health services research, the system analytical model is a framework often used for evaluation. Examples of its use in OHSs are described by Cho et al and by Parillo. ${ }^{49}$ In Finland, Husman et al applied this concept to develop and evaluate a national OHSs system for farmers. ${ }^{9}$ Input, process, and outcome components were distinguished. To achieve the ultimate goal, a change in prevalence of work related diseases, intermediate objectives - for example, change in work methods and work behaviour-were chosen. This shows that it might be possible to evaluate an OHS system at different levels of objectives, which could increase the efficiency of the analysis. 


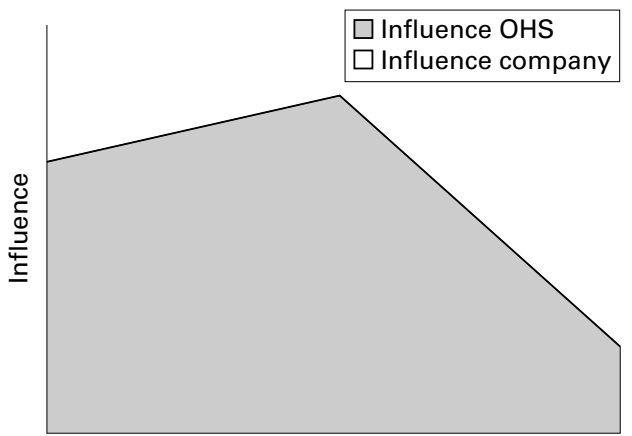

Identification Assessment

Control

Figure 1 Model of changing impact of OHS activities during risk identification, assessment, and control of a work related risk. ${ }^{50}$

A more general problem in evaluation studies in occupational health care, is the fact that in the ultimate outcome of OHSs, other actors and factors may play important and sometimes more decisive parts. $^{50}$ This is schematically outlined in figure 1. During the successive phases of identification of occupational health risk, risk assessment and control of a work related health risk, which influence OHSs, vary considerably. Risk identification and risk assessment are important tasks of OHSs, and occupational health professionals in OHSs are expected to play a competent and active part in this. However, the actual control of risk itselffor example, changes in work conditions-is the direct responsibility of the employer, to a much larger degree than of the employee. When the performed activities do reach the final goal, it is not necessarily a failure of the evaluated OHS system as such. Maybe the OHS activities were carried out correctly, but for some reason the employer totally ignored all advice. In evaluation of the outcome of OHSs or OHS activities such mechanisms have to be taken into account. This again stresses the importance of combining outcome evaluation with process measurements.

A general model for evaluation of OHSs

For practical and for methodological reasons, it is often not feasible to study long term outcome objectives such as a decrease in the prevalence of work related diseases. Therefore, in studies that evaluate OHSs, emphasis will be on intermediate objectives such as changes in exposure or changes in knowledge, skills, attitudes, or work methods in target groups. Activities of OHSs often have only indirect influence on the ultimate outcome on work and health. The output or product of most OHS activities is advice. This advice may be given to an individual employee, to a group of employees, or to a supervisor or manager. In evaluation of OHSs, this advice can be regarded as an essential link between the process of delivery of care and the outcome. ${ }^{28}$ From concepts of evaluation research, a general model for evaluation of OHSs can be extracted. ${ }^{51}$ This general model (illustrated by an OHSs approach on prevention and control of noise induced hearing loss), showing the different dimensions of aetiological research and evaluation or intervention research, is presented in figure 2 .

EMPIRICAL STUDIES ON EVALUATION OF OHSS OR OHS INSTRUMENTS

A total of 52 empirical studies met the inclusion criteria. Most of the publications come from four countries: United States, United Kingdom, Netherlands, and Finland. The studies were categorised according to their main object; 21 studies were directed at input or structure of OHSs, 13 studies deal with processes, six with output, and 13 with outcome of OHSs or OHS instruments. Two publications did refer to the same study and one study was directed at both input and

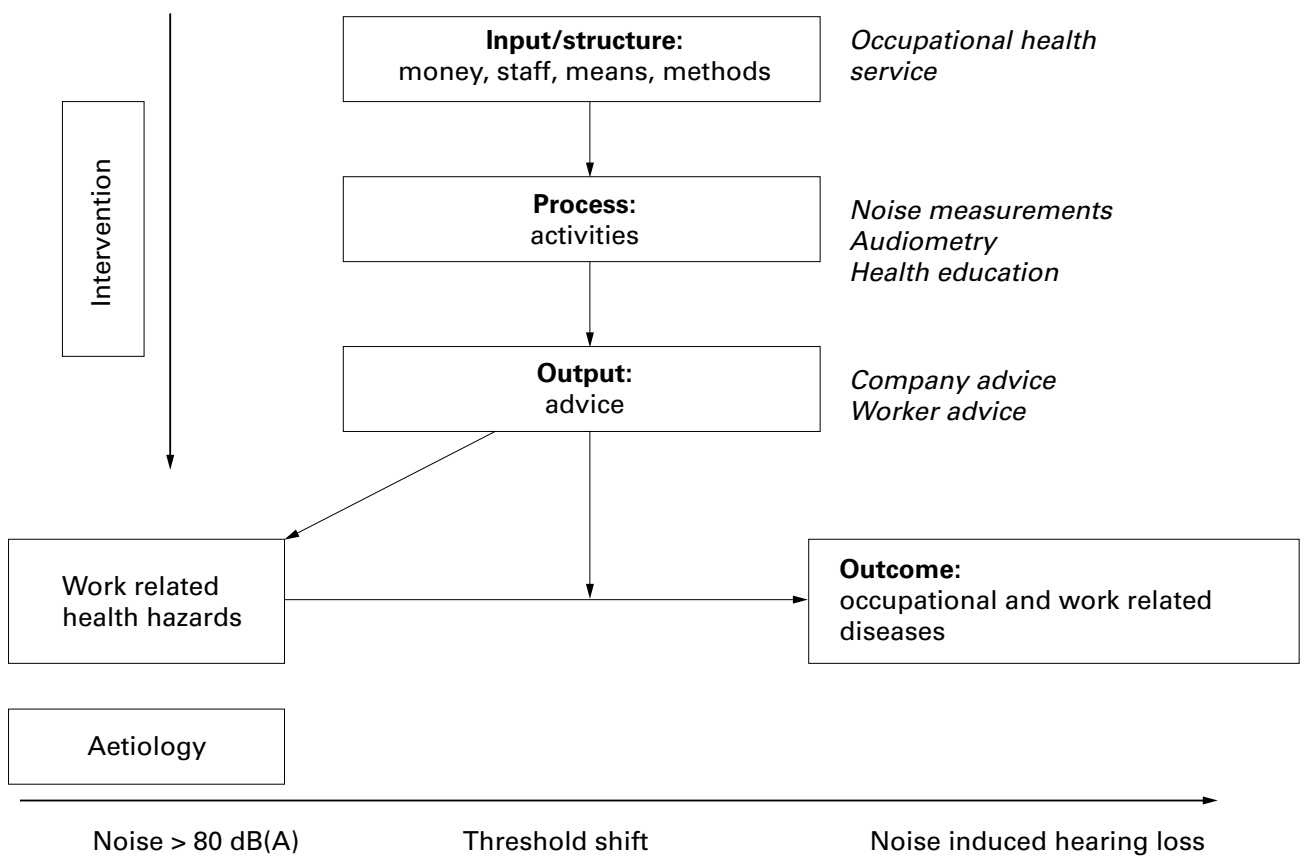

Figure 2 General model for evaluation of $\mathrm{OHSs} .{ }^{51}$ 
output. Tables 2-6 summarise the studies and their main findings. In 28 studies, general aspects of $\mathrm{OHSs}$ were investigated, whereas the other 24 studies dealt with specific OHS activities or instruments, in particular preemployment examination and (periodic) occupational health surveillance.

Evaluation of input or structure of OHSs

We have made a distinction between characteristics of OHS systems or provider and characteristics of clients (table 2). Almost all of the studies reviewed on input or structure of OHSs were descriptive, non-experimental, and cross sectional. In only two studies, data of repeated measurements were used and a trend was analysed, although comparable data over time were few and inaccessibile, as the authors indicate themselves..$^{52}$ The study by Woodall et al is the only one that compared the results of the study group (frequent visitors of the OHSs) with a reference group (random sample of non-frequent visitors), but was hampered by a low response in both groups. ${ }^{52}$ In most of the studies, the data were collected by postal or interviewer administered questionnaire. In six studies, additional health services data or case records were used..$^{5255596870}$ Because of the descriptive character, most studies lacked statistical analyses of the results. In one study, ${ }^{46}$ multivariate analysis was used to explain the findings and in another study, ${ }^{55}$ Cohen's $\mathrm{ks}$ were calculated to study the agreement between physicians' and employees' perceptions of work relatedness of the health problems. In a few other studies, descriptive statistics were presented.

With the exception of the study on sickness absence and fitness for work by Agius et al, ${ }^{68}$ the objectives of the studies on input or structure of OHSs were not evaluated against certain criteria. The information in most studies in this section may therefore be considered more as a description of input and structure of OHSs in different countries than a real evaluation. A real evaluation would require available standards of (best) practice or well defined criteria of care. Despite this general limitation and the heterogeneous character of the study objectives, some general trends emerge from the findings. Five studies, conducted in different populations, all reported a shortage of physicians or specialists in occupational medicine in the United States and a shift away from in factory OHSs to freestanding OHSs, often operating on a commercial basis..$^{52-55}{ }^{60}$ Examination of and advice on matters of work environment and preventive health examinations of workers are, in different countries, seen as the most important OHSs tasks, in particular by employees. ${ }^{63}{ }^{66-69}$ For other tasks - for example, rehabilitation or public health oriented health promotion-less agreement exists between employers, employees, and occupational physicians. ${ }^{6769}$ These preferences or perceptions of the role of OHSs are, however, not always reflected in the actual use of OHSs or in the work content of occupational physicians in practice. In many developing countries, OHSs are often concentrated on the predominant health problems like malnu- trition and only to a small part on occupationally related ailments. ${ }^{58}$ In a study of OHSs in San Diego, it was reported that employers responding to the survey cited acute care as the service most often obtained from outside providers. ${ }^{52}$ In Finland workers often use OHS units for general practitioners' services. ${ }^{46}$ In the United Kingdom, assessment of fitness for work or sickness absence ranked first in use of physicians' time, ${ }^{56}$ and in Norway, $30 \%$ of the working time of occupational physicians was directed to curative activities. ${ }^{57}$ This was also the case in the developed countries, the actual practice does not always follow the demands of the clients or customers of the OHSs.

\section{Evaluation of process of OHSs or OHS} instruments

As in the previous section, most of the studies on processes of OHSs used a non-experimental and cross sectional study design. Although the emphasis is still on description of the activities of OHSs (what do they do?), some studies have a more evaluative nature (how well is it done?). Sugita et al studied the quality of biological monitoring methods in use in OHSs and saw a gradual improvement in scores on a well defined evaluation system between 1980 and $1987 .{ }^{71}$ In an external audit of occupational medical consultation records, Agius et al used a set of quality criteria to judge the medical consultation process. ${ }^{74}$ Because the "career" occupational physicians had significantly better scores than the "non-career" occupational physicians (usually part time general practitioners), the authors stress the importance of further training of physicians practising occupational medicine. Behrens and Müller evaluated the self reported compliance of company doctors with the workplace related activities as required by the German law on work security. ${ }^{72}$ They found that only one third of the responders carried out these activities. By contrast with Agius et al, they saw no significant effect of the qualifications of the physicians; more important were compulsory factors such as state regulations or a prevention oriented policy in the company. In a study on pre-employment examinations, the variability between experienced occupational physicians in a governmental OHS was used as a measure of reproducibility and thus as a measure of quality. ${ }^{77}$ Poor agreement was found, suggesting that the validity of judgement of medical fitness for a job may be seriously questioned, even when detailed fitness criteria are available. In another study, the value of haematological screening as part of pre-employment examination in healthcare workers was questioned because in half of the cases abnormalities were found, but they almost never affected the decision on fitness for employment. ${ }^{76}$ More positive conclusions were drawn in a study on the feasibility of preemployment screening on occupational allergens in a vocational school of bakers. ${ }^{79}$ Because of the specificity of the findings (positive skin prick tests to wheat flour, rye, and amylase), the fact that $4 \%$ of the total group of these young bakers already had respiratory symptoms after short exposure, and the opinion that the social 
Table 2 Evaluation studies on input or structure of occupational health services (OHSs)

\begin{tabular}{|c|c|c|}
\hline Study & Objective & Study design \\
\hline \multicolumn{3}{|c|}{ Occupational health services system and provider characteristics: } \\
\hline Guidotti and Kuetzing ${ }^{52} 1985$ (USA) & Profile and trends in occupational health services in San Diego between 1974 and 1984 & $\begin{array}{l}\text { Descriptive study cross sectional } \\
\text { (with trend analysis) }\end{array}$ \\
\hline Brandt-Rauf $e$ t a ${ }^{53} 1988$ (USA) & $\begin{array}{l}\text { Current use and perceived future need for occupational physicians in non-industrial } \\
\text { occupational health services settings }\end{array}$ & Descriptive study cross sectional \\
\hline Pransky ${ }^{54} 1990$ (USA) & Characteristics of occupational medicine (occupational medicine) specialists & Descriptive study cross sectional \\
\hline Ducatman et a $\bar{p}^{5} 1991$ (USA) & Variation in occupational physician employment in large companies & Descriptive study cross sectional \\
\hline Agius et $a \bar{l}^{6} 1993(\mathrm{UK})$ & Characteristics of occupational physicians and involvement in audit & Descriptive study cross sectional \\
\hline Hulshof et $a \check{\ell}^{00} 1993$ (Netherlands) & $\begin{array}{l}\text { Occupational health services involvement in control of adverse effects of whole body } \\
\text { vibration }\end{array}$ & Descriptive study cross sectional \\
\hline Wannag and Nord ${ }^{57} 1993$ (Norway) & Work content of occupational physicians & Descriptive study cross sectional \\
\hline Isah et a $\bar{l}^{8} 1996$ (Nigeria) & Profile of occupational health services in manufacturing industries in Nigeria & Descriptive study cross sectional \\
\hline \multicolumn{3}{|c|}{ Client characteristics and use of occupational health services: } \\
\hline Woodall et a $a P^{9} 1987$ (USA) & Patient characteristics (frequent visitors) & Descriptive study 1 year follow up \\
\hline Pedersen and Sieber, ${ }^{60} 1989$ (USA) & Worker acces to health care as a result of employment & $\begin{array}{l}\text { Descriptive study cross sectional } \\
\text { (with trend analysis) }\end{array}$ \\
\hline Spiegel and Yassi, ${ }^{61} 1989$ (Israel) & $\begin{array}{l}\text { Employers' need, use, accessibility and demand of occupational health services' for } \\
\text { small workplaces }\end{array}$ & Descriptive study cross sectional \\
\hline Barron et al ${ }^{62} 1990$ (South Africa) & Provision of occupational health services in the manufacturing industry & Descriptive study cross sectional \\
\hline Plomp ${ }^{63} 1992$ (Netherlands) & $\begin{array}{l}\text { Employees' attitude towards occupational health services and occupational physicians } \\
\text { (occupational physician) }\end{array}$ & Descriptive study cross sectional \\
\hline Dryson $^{64} 1993$ (New zealand) & $\begin{array}{l}\text { Occupational health needs assessment and use of services of workers in small } \\
\text { companies }\end{array}$ & Descriptive study cross sectional \\
\hline Plomp ${ }^{65} 1993$ (Netherlands) & Employees' and physicians' perceptions of work relatedness of problems & Descriptive study cross sectional \\
\hline Räsänen $e t a l^{46} 1993$ (Finland) & Use of occupational health services & Descriptive study cross sectional \\
\hline Ritchie and McEwen ${ }^{66} 1994$ (UK) & Employee perception of role of occupational health services & Descriptive study cross sectional \\
\hline Williams et $a l^{67} 1994$ (UK) & $\begin{array}{l}\text { Perception of role of occupational health services by managers, employee representatives } \\
\text { and occupational physicians }\end{array}$ & Descriptive study cross sectional \\
\hline Agius et $a l^{68} 1995(\mathrm{UK})$ & $\begin{array}{l}\text { Information from managers or supervisors in referrals for sickness absence or fitness for } \\
\text { work }\end{array}$ & $\begin{array}{l}\text { Performance study stratified } \\
\text { sample over a } 26 \text { month period }\end{array}$ \\
\hline Dryson $^{69} 1995$ (New Zealand) & Workers' preferences in delivery of occupational health services in small industry & Descriptive study cross sectional \\
\hline Plomp ${ }^{70} 1996$ (Netherlands) & Accessibility and use of occupational health services & Descriptive study cross sectional \\
\hline
\end{tabular}

cost at this age is more acceptable, the authors concluded that pre-employment screening in this particular occupational group may be useful. Mikovic-Kraus and Macan gave a positive opinion on the usefulness of pre-employment patch testing to prevent occupational contact allergy in industries at risk. ${ }^{80}$ The paper is, however, not particularly informative, in particular with respect to the selection of the population used. Some of the studies on process are the result of medical audit from quality assurance procedures, in particular in occupational health departments within the National Health Service (NHS) in the United Kingdom. ${ }^{7475} 78$ The study of Braddick et al shows a distinct variance in comprehensiveness of pre-employment examination procedures in different departments with slightly higher rejection or restriction rates in the OHSs which examine more comprehensively. ${ }^{75}$ Whitaker and Aw confirmed the variation in examining practice, but they found no significant difference in rejection rates between various assessment methods. ${ }^{78}$ The authors of both studies questioned the efficiency of the current preemployment practice in the NHS and made recommendations for pre-employment assessments targeted at specific occupational groups. The study by Agius et al also included an attempt to "audit the audit"; it evaluated the possible benefit of audit on the medical consultation process and found it as yet to be only of minor significance. ${ }^{74}$ Quality assurance procedures were also used by Udasin et al in evaluating the periodic occupational health surveillance practice. ${ }^{81}$ By auditing medical 
Table 2 Continued

\begin{tabular}{|c|c|c|}
\hline Methods & Study group/sample size & Main findings \\
\hline $\begin{array}{l}\text { Analysis of demographic and health } \\
\text { services data; questionnaire survey }\end{array}$ & $\begin{array}{l}\text { Occupational health services (facilities and } \\
\text { human resources) in San Diego; } 130 \\
\text { employers (response: } 29 \% \text { in } 1981 \text { and } 22 \% \\
\text { in 1983) }\end{array}$ & $\begin{array}{l}\text { Decline in in-plant occupational health services facilities; increase of } \\
\text { freestanding industrial medical clinics; certified occupational medicine } \\
\text { specialists remain few; more approval of acute care, screening and } \\
\text { employee assistance than preventive services }\end{array}$ \\
\hline Postal questionnaire & $\begin{array}{l}\text { Random sample of group medical practices } \\
(\mathrm{n}=100, \text { response } 44 \%) \text { and health } \\
\text { maintenance organisations }(n=100,35 \%)\end{array}$ & $\begin{array}{l}44 \text { Group practices employ in total only } 18 \text { occupational physician's and } 11 \\
\text { occupational health nurses; } 35 \text { health maintenance organisations employ } \\
20 \text { occupational physicians and } 7 \text { nurses; a } 200 \% \text { increase of occupational } \\
\text { health personnel between } 1987 \text { and } 1997 \text { is foreseen }\end{array}$ \\
\hline Postal questionnaire & $\begin{array}{l}1056 \text { Physicians occupational medicine certified } \\
\text { response: } 67 \%\end{array}$ & $\begin{array}{l}\text { Number of occupational medicine specialists less than expected; } 35 \% \\
\text { employed in one company, } 17 \% \text { academic setting, } 12 \% \text { in federal or } \\
\text { military government, } 8 \% \text { independent clinic; younger physicians less often } \\
\text { in industry }\end{array}$ \\
\hline $\begin{array}{l}\text { Interview of corporate officials and } \\
\text { analysis of occupational physician } \\
\text { employment data }\end{array}$ & $\begin{array}{l}25 \text { Largest US companies ( } \mathrm{n}=514 \text { occupational } \\
\text { physicians) }\end{array}$ & $\begin{array}{l}\text { Oil and chemical plants employ largest number of occupational physicians } \\
\text { per employee; positive relation between company profits and number of } \\
\text { occupational physicians }\end{array}$ \\
\hline Postal questionnaire & $\begin{array}{l}200 \text { Occupational medicine practitioners in UK } \\
\text { response: } 83 \%\end{array}$ & $\begin{array}{l}\text { Wide diversity in specialty characteristics Assessment of fitness for work or } \\
\text { sick leave ranked first in physicians' time } 48 \% \text { engaged in audit; in } 18 \% \\
\text { audit of structure, process and outcome of care }\end{array}$ \\
\hline Postal questionnaire & $\begin{array}{l}\text { All officially registered occupational health } \\
\text { services }(n=166) \text {; response rate } 67 \%\end{array}$ & $\begin{array}{l}75 \% \text { of occupational health services judge their expertise and ability in } \\
\text { prevention of effects related to whole body vibration as insufficient; small } \\
\text { impact of occupational health services }\end{array}$ \\
\hline Interview by telephone & $\begin{array}{l}50 \text { Occupational physicians, ( } 5 \text { workdays per } \\
\text { occupational physician) }\end{array}$ & $\begin{array}{l}40 \% \text { of work time concerned work matters and } 30 \% \text { curative activities; Work } \\
\text { situation or type of occupational health services cannot explain observed } \\
\text { differences in work content }\end{array}$ \\
\hline $\begin{array}{l}\text { Questionnaire survey observation } \\
\text { (visits) }\end{array}$ & $\begin{array}{l}123 \text { Occupational health services (randomly } \\
\text { selected) response rate: } 91 \%\end{array}$ & $\begin{array}{l}\text { Poor provision of occupational health services in small industries; only } 4.3 \% \\
\text { of cases seen are occupationally related. }\end{array}$ \\
\hline $\begin{array}{l}\text { Analysis of } 1 \text { year occupational health } \\
\text { services visits and sickness absence } \\
\text { records; Questionnaire survey }\end{array}$ & $\begin{array}{l}\text { Frequent visitors of occupational health services } \\
\text { of automobile plant }(n=235) \text {; non-frequent } \\
\text { visitors (random sample } n=199 \text { ) response: } \\
19 \%\end{array}$ & $\begin{array}{l}16 \% \text { of employees accounted for } 50 \% \text { of all visits; frequent visitors had } \\
\text { higher absence rates and greater health risk; black and young employees } \\
\text { were overrepresented }\end{array}$ \\
\hline $\begin{array}{l}\text { Questionnaires in } 2 \text { national surveys by } \\
\text { NIOSH in } 1972 \text { and } 1981\end{array}$ & $\begin{array}{l}4016 \text { Companies in } 1972 \text { ( } 8133 \text { workers) and } \\
4258 \text { companies in } 1981 \text { ( } 1572638 \text { workers) } \\
\text { in private sector }\end{array}$ & $\begin{array}{l}\text { Increase of delivery of off site contractual medical care (instead of on site } \\
\text { physicians); large increase in the use of screening tests and decreased use of } \\
\text { pre-employment examinations }\end{array}$ \\
\hline Interview & $\begin{array}{l}51 \text { Plant managers, size stratified sample from a } \\
\text { community health centre area }\end{array}$ & $\begin{array}{l}\text { Use of occupational health services by small workplaces is restricted, few } \\
\text { small workplaces have met mandatory regulations; a community health } \\
\text { centre based occupational health service deemed to be acceptable }\end{array}$ \\
\hline Postal questionnaire & $\begin{array}{l}760 \text { Manufacturing organisations (response } \\
\text { rate } 51 \% \text { ) }\end{array}$ & $\begin{array}{l}\text { General deficiency in the quantity of occupational health services; salaried } \\
\text { employees better off than wage earners; no substantial change since } 1976\end{array}$ \\
\hline Interview & $\begin{array}{l}3 \text { companies with different occupational health } \\
\text { service setting, selected sample of employees } \\
(n=310)\end{array}$ & $\begin{array}{l}\text { Examination of workers and working conditions seen as most important } \\
\text { occupational health services task; lack of clarity about loyalty and } \\
\text { independence of occupational physician in practice; company and } \\
\text { occupational health services characteristics had little effect on workers' } \\
\text { perception/appreciation }\end{array}$ \\
\hline Interviewer administered questionnaire & $\begin{array}{l}200 \text { Workers in } 35 \text { small companies (cluster } \\
\text { sampling technique) factory response: } 70 \%\end{array}$ & $\begin{array}{l}15 \% \text { assessed working conditions as poor, } 38 \% \text { had needed occupational } \\
\text { health information/advice; boss and general practicioner commonest } \\
\text { sources of information on occupational health issues }\end{array}$ \\
\hline Interview & $\begin{array}{l}\text { Employees in } 3 \text { companies }(n=313) \text { and } \\
\text { occupational physicians in these companies } \\
(n=6)\end{array}$ & $\begin{array}{l}\text { Large disagreement between physicians' and employees' judgement; } \\
\text { socioeconomic implications of the label work relatedness is important } \\
\text { factor in this discrepancy }\end{array}$ \\
\hline Computer assisted telephone interview & $\begin{array}{l}\text { Employees, random sample from national } \\
\text { health survey }(n=1029)\end{array}$ & $\begin{array}{l}\text { Employees often use occupational health services units for general } \\
\text { practitioner services; availability of occupational health services did not } \\
\text { increase overall use of physicians' services (coverage of occupational health } \\
\text { services: } 79 \% \text { ) }\end{array}$ \\
\hline Postal questionnaire & $\begin{array}{l}300 \text { Employees (public sector organisation) } \\
\text { response: } 46 \%\end{array}$ & $\begin{array}{l}\text { Monitoring the working environment by } 60 \% \text { seen as the prime function of } \\
\text { occupational health services; stress greatest health concern }\end{array}$ \\
\hline Postal questionnaire & $\begin{array}{l}264 \text { Managers, } 68 \text { union representatives, and } \\
145 \text { occupational physicians; response: } \\
51 \%-61 \%\end{array}$ & $\begin{array}{l}\text { Advice on work environment and on medical retirement seen as most } \\
\text { important occupational health services tasks; for other tasks (eg } \\
\text { rehabilitation) less agreement }\end{array}$ \\
\hline Audit by external peer review & $\begin{array}{l}\left.\text { (Total sample: see Agius }{ }^{74} 1994\right) 162 \text { randomly } \\
\text { selected referral letters in case records }\end{array}$ & $\begin{array}{l}\text { Referral requests adequate in specifying duration of absence; information on } \\
\text { other relevant issues less frequent, only } 12 \% \text { provided employees' job } \\
\text { description }\end{array}$ \\
\hline Interviewer administered questionnaire & $\begin{array}{l}200 \text { workers in } 35 \text { small companies (see } \\
\text { Dryson }^{64} 1993 \text { ) }\end{array}$ & $\begin{array}{l}\text { Good support for work protective or preventive tasks of occupational health } \\
\text { services in small industry; little demand for general health promotion } \\
\text { activities like lifestyle issues }\end{array}$ \\
\hline $\begin{array}{l}\text { Rates of use from medical records; } \\
\text { Interview }\end{array}$ & $\begin{array}{l}\text { Random sample of employees }(n=911) \\
\text { interview: selected sample (see Plomp }{ }^{63} \text { ) }\end{array}$ & $\begin{array}{l}\text { Use of occupational health services is determined by organisation of its acces; } \\
\text { open consultation hour has restricted function for occupational health } \\
\text { problems }\end{array}$ \\
\hline
\end{tabular}

records of 17 different occupational health facilities and comparing them against performance standards, they studied the quality of medical surveillance programmes for hazardous waste workers. They found the level of medical surveillance to vary dramatically among the providers.

\section{Evaluation of output of OHSs}

The output of OHSs is an essential link between process and outcome. One study evaluated the output of medical consultations, one was directed to pre-employment examinations, two to periodic health examinations, and two studies dealt with the output of workplace investigations. Agius et al examined both input aspects (the quality of the referrals from managers or supervisors) and the output (the occu- pational physicians' response) of OHSs consultations on sickness absence and fitness to continue work. ${ }^{68}$ Although the quality of the input was often found to be poor, the quality of the physicians' response (the way physicians answered the questions of the managers or supervisors and gave advice to both managers and employees) was rated higher. Moreover, the frequency of occupational physicians' responses was often higher than the frequency of questions posed to them, suggesting added value of the physicians in the formulation of the problem. De Kort et al analysed all preemployment examinations of applicants for governmental functions during a 6 year period. ${ }^{85}$ Applicants $>50$ years old were four times more likely to be rejected than applicants between 20 and 30 years old. Only for 

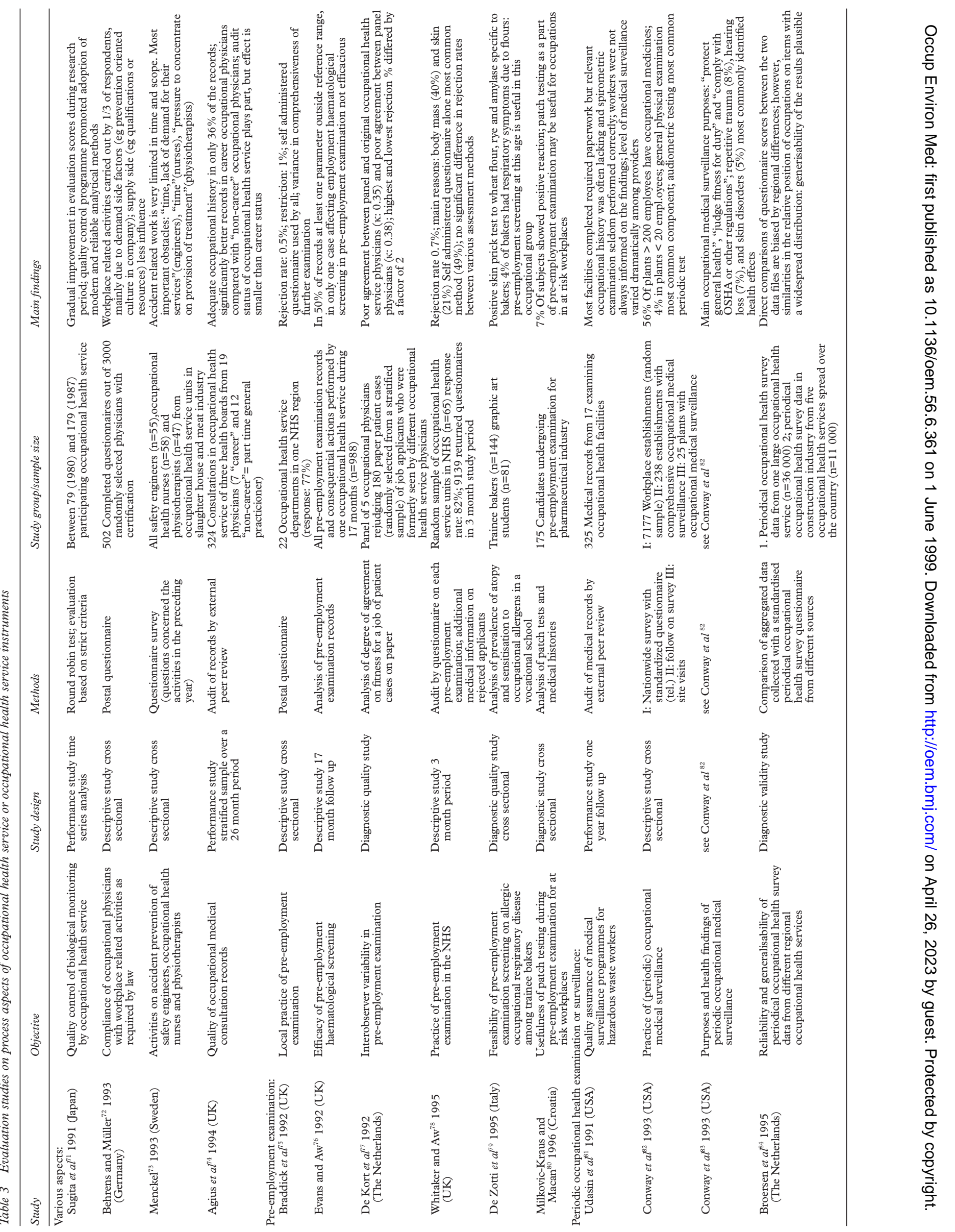
Table 4 Evaluation studies on output of occupational health service or occupational health service instruments

\begin{tabular}{|c|c|c|c|c|c|}
\hline Study & Objective & Study design & Methods & Study group/sample size & Main findings \\
\hline \multicolumn{6}{|l|}{ Medical consultation: } \\
\hline Agius et al ${ }^{68} 1995$ (UK) & $\begin{array}{l}\text { Responses and response } \\
\text { time of occupational } \\
\text { physicians in sickness } \\
\text { absence or fitness for } \\
\text { work consultations }\end{array}$ & $\begin{array}{l}\text { Performance study } \\
\text { stratified sample } \\
\text { over a } 26 \text { month } \\
\text { period }\end{array}$ & $\begin{array}{l}\text { Audit by external } \\
\text { peer review }\end{array}$ & $\begin{array}{l}162 \text { Consultation } \\
\text { records from referrals } \\
\text { dealing with sickness } \\
\text { absence or fitness for } \\
\text { work }\end{array}$ & $\begin{array}{l}\text { Physicians' response rate high } \\
\text { (96\%) for 'likely date of return to } \\
\text { work' but lower for other items, } \\
\text { eg work limitations; frequency of } \\
\text { occupational physicians' } \\
\text { responses higher than frequency } \\
\text { of questions added value of } \\
\text { occupational physicians in } \\
\text { formulation of the problem; no } \\
\text { correlation between response } \\
\text { time and completeness of records }\end{array}$ \\
\hline $\begin{array}{l}\text { Pre-employment examination: } \\
\text { de Kort et a } l^{55} 1991 \\
\text { (The Netherlands) }\end{array}$ & $\begin{array}{l}\text { Efficacy of } \\
\text { pre-employment } \\
\text { examination } \\
\text { (pre-employment } \\
\text { examination) in a large } \\
\text { occupational health } \\
\text { service }\end{array}$ & Case-referent study & $\begin{array}{l}\text { Analysis of } \\
\text { pre-employment } \\
\text { examination } \\
\text { records }\end{array}$ & $\begin{array}{l}\text { All pre-employment } \\
\text { examination in a large } \\
\text { governmental } \\
\text { occupational health } \\
\text { service during a } 6 \\
\text { year time period } \\
\text { (101754 cases) }\end{array}$ & $\begin{array}{l}\text { Overall rejection rate } 0.6 \%, \\
\text { applicants }>50 \text { years fourfold } \\
\text { increased risk; accepted and } \\
\text { rejected applicants had diagnoses } \\
\text { in common; poor efficacy of } \\
\text { pre-employment examination in } \\
\text { reducing absenteeism and } \\
\text { disablement }\end{array}$ \\
\hline \multicolumn{6}{|c|}{ Periodic occupational health examination or surveillance: } \\
\hline $\begin{array}{l}\text { Hessel and Zeiss }{ }^{86} 1988 \\
\text { (South-Africa) }\end{array}$ & $\begin{array}{l}\text { Efficacy of periodic } \\
\text { examination with respect } \\
\text { to screening purposes, } \\
\text { assessing fitness for } \\
\text { work, and identifying } \\
\text { compensable diseases }\end{array}$ & Patient series & $\begin{array}{l}\text { Reanalysis of } \\
\text { periodic } \\
\text { examination } \\
\text { findings by two } \\
\text { specialists }\end{array}$ & $\begin{array}{l}\text { Consecutive periodic } \\
\text { examinations in } \\
\text { mining industry } \\
\text { during a } 6 \text { month } \\
\text { period ( } \mathrm{n}=7758)\end{array}$ & $\begin{array}{l}\text { Only hearing loss and hypertension } \\
\text { occured frequently enough for } \\
\text { screening; periodic examinations } \\
\text { useful for assessing fitness for } \\
\text { work ( } 8 \% \text { of workers required } \\
\text { consideration), but not in } \\
\text { identifying workers with } \\
\text { compensable diseases }\end{array}$ \\
\hline $\begin{array}{l}\text { Rose and Bengtsson }{ }^{87} 1991 \\
\text { (Sweden) }\end{array}$ & $\begin{array}{l}\text { Efficacy of a health } \\
\text { examination programme } \\
\text { based on laboratory } \\
\text { examinations }\end{array}$ & Patient series & $\begin{array}{l}\text { Retrospective } \\
\text { analysis of case } \\
\text { records of } \\
\text { participants }\end{array}$ & $\begin{array}{l}117 \text { White collar } \\
\text { workers selected by } \\
\text { age or work related } \\
\text { risks) from } 2000 \\
\text { employees }\end{array}$ & $\begin{array}{l}\text { Few measures were taken as a result } \\
\text { of the laboratory examinations. } \\
\text { The programme seemed to be of } \\
\text { limited value }\end{array}$ \\
\hline \multicolumn{6}{|l|}{ Workplace investigation: } \\
\hline Mattila $^{88} 1989$ (Finland) & $\begin{array}{l}\text { Usefulness of new } \\
\text { workplace investigation } \\
\text { method in construction } \\
\text { industry }\end{array}$ & $\begin{array}{l}\text { Non-experimental } \\
\text { before-after }\end{array}$ & $\begin{array}{l}\text { Comparison of } \\
\text { output of } \\
\text { workplace } \\
\text { investigation } \\
\text { before and after } \\
\text { introduction of a } \\
\text { new method }\end{array}$ & $\begin{array}{l}8 \text { Site visits on } 3 \\
\text { building sites ( } 414 \\
\text { job analyses) } \\
\text { questionnaire survey } \\
\text { of workers }(n=531 ; \\
\text { response } 80 \%)\end{array}$ & $\begin{array}{l}\text { Increase of the number and quality } \\
\text { of proposals for preventive } \\
\text { measures; improvement of } \\
\text { occupational health service } \\
\text { surveillance programme on basis } \\
\text { of new method possible; new } \\
\text { method superior to previous } \\
\text { practice and implemented at } \\
\text { moderate cost }\end{array}$ \\
\hline Peretz et $a l^{89} 1992$ (Israel) & $\begin{array}{l}\text { Output of occupational } \\
\text { health hazard surveys } \\
\text { and implementation of } \\
\text { recommendations of an } \\
\text { occupational health } \\
\text { service unit }\end{array}$ & $\begin{array}{l}\text { Judgemental } \\
\text { (constituency } \\
\text { approach) }\end{array}$ & $\begin{array}{l}\text { Interview/ } \\
\text { questionnaire }\end{array}$ & $\begin{array}{l}\text { Managers and safety } \\
\text { officers of } 100 \\
\text { workplaces }(=79 \% \text { of } \\
\text { all workplaces } \\
\text { surveyed by the unit } \\
\text { in 1988) }\end{array}$ & $\begin{array}{l}80 \% \text { Satisfied with quality of the } \\
\text { report } 51 \% \text {; of recommendations } \\
\text { fully implemented and } 33 \% \text { not } \\
\text { at all; implementation not related } \\
\text { to actual hazard but to existence } \\
\text { of regulations covering it }\end{array}$ \\
\hline
\end{tabular}

musculoskeletal disorders, was an association between diagnostic category and job demands apparent. Accepted and rejected applicants had diagnoses in common. These findings suggest poor efficacy of the pre-employment examination for reducing absenteeism and disablement. Hessel and Zeiss evaluated a periodic examination programme in the mining industry and concluded that it was probably useful as a means of assessing fitness for work, but not so much in health screening or in identifying compensable occupational diseases. ${ }^{86}$ Rose and Bengtsson reported the limited value of ECG and laboratory examination as a part of a general health examination of employees. ${ }^{87}$ Few measures were taken as a result of these examinations, other than re-examinations. Mattila studied the output of a new systematic method of investigating the workplace (based on job analysis, worker involvement, and group problem solving) used by OHS teams in the construction industry. ${ }^{88}$ In a non-experimental before-after study design, the new method was found to be better than the previous examination method: it increased the number and quality of proposals to line management for preventive measures and improved the occupational healthcare programme. In a questionnaire survey, Peretz et al evaluated workplace investigation reports, aiming to assess the satisfaction of managers and safety officers with the content and clarity of the reports. ${ }^{89}$ The study was also dealing with an outcome aspect: the extent to which the recommendations, given in the reports, were implemented after 2 years. Satisfaction with the quality of the reports was high but half of the recommendations were not or partially carried out.

\section{Evaluation of outcome of OHSs or OHS instruments}

The effects of care delivered by OHSs on work environment and health status of individual employees or worker populations can be regarded as the ultimate outcome. Although seen by some authors as a process measure, the degree of clients' satisfaction with care is often used as an outcome variable. In this review, we have classified three studies on satisfaction with the care delivered by OHSs under outcome evaluation (table 5).

Seven of the outcome studies evaluated care delivery by OHSs in general. The other outcome studies dealt with a specific OHS activity. From a methodological point of view, the research designs of most of the outcome evaluation studies are weak. In only one study was a quasi-experimental study design applied. ${ }^{91}$ Another study used a before-after design with repeated measurements. ${ }^{102}$ Lowenthal made internal comparisons in a group 

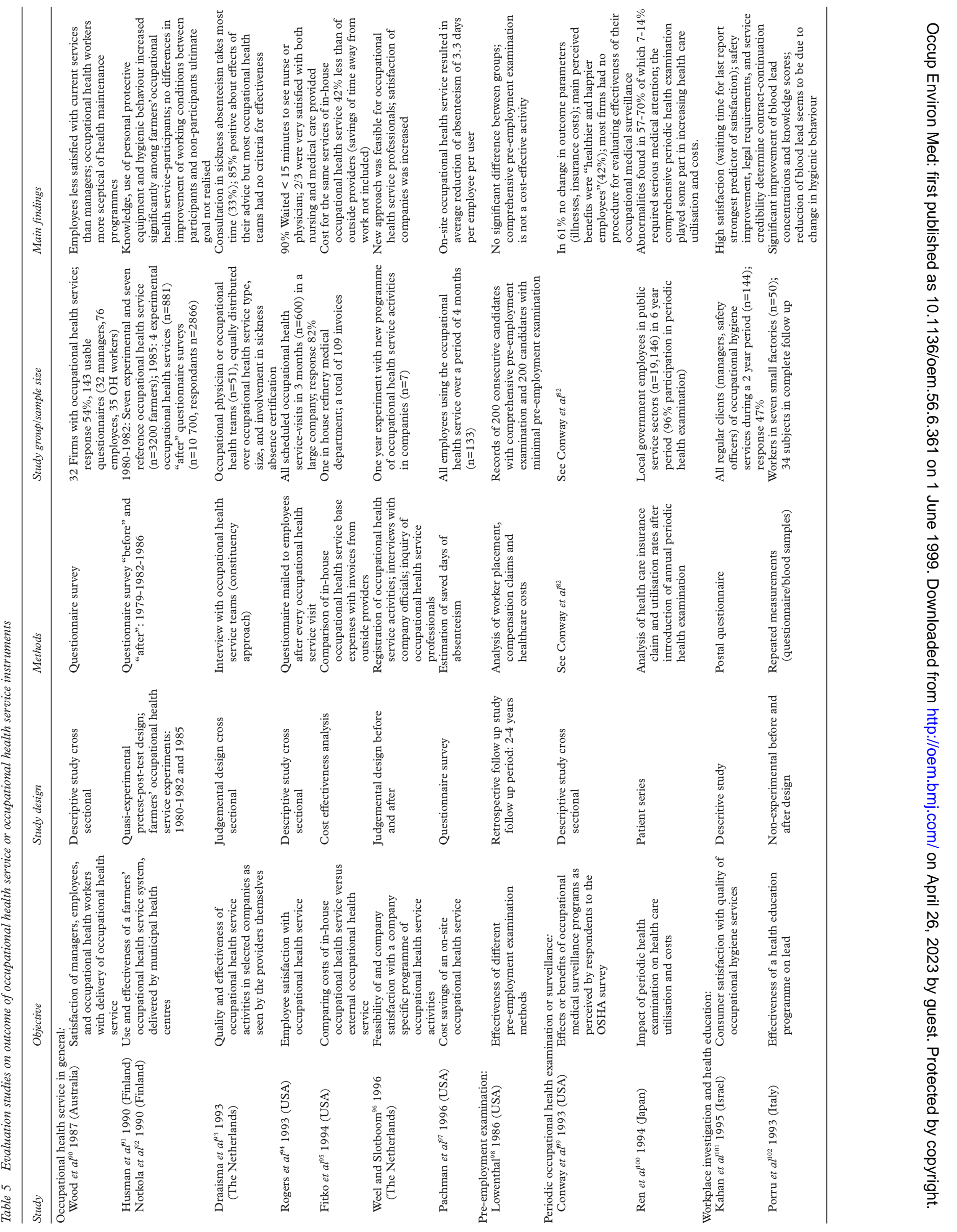
of pre-employment examinations. ${ }^{98}$ Most of the other studies were descriptive. Wood et al investigated the satisfaction of managers, employees, and the OHS workers involved with the delivery of care by OHSs in 32 firms in industry. ${ }^{90}$ Polarised views were found: employees were less satisfied than managers, with OHS workers in between. By contrast, Rogers et al reported high employee satisfaction with both nursing care and physicians' services from an OHS in a large pharmaceutical company. ${ }^{94}$ High levels of satisfaction were also found in a study of Kahan et al among managers and safety officers with accessibility, quality, and cost of occupational hygiene services, although the response rate of only $47 \%$ may be selective. ${ }^{101}$ The publications of Husman et al and Notkola et al, both referring to the same study, described the development and evaluation of a national farmers' OHS system in Finland between 1979 and $1987 . .^{91}{ }^{92}$ The functional adequacy (with input and process aspects) and the effectiveness of this system was evaluated. Unfortunately, information on the evaluation of OHSs in both articles on methodology and design of this unique large scale study was not optimal; in particular the assignment of farmers to the experimental and the control group and the relation between the questionnaire surveys and the experiments. When improvement in working conditions was the ultimate indicator of the outcome evaluation, the system was not effective: differences between participants and non-participants were negligible. However, farmers' knowledge on health hazards, use of protective equipment, and occupational hygienic behaviour scored significantly higher among participants than among the reference group, indicating that on the process level the OHS system was successful. As a possible reason for this discrepancy, the authors suggest that the farmers' OHS system may be concentrated too much on the use of personal protective equipment. Draaisma et al evaluated the effectiveness of OHS activities in selected companies by interviewing the OHS teams themselves (constituency approach). ${ }^{93}$ Most of the teams were positive in their assessment of the results of their advice to the companies but their criteria for defining effectiveness were vague and output criteria for their own activities were lacking. Weel and Slotboom evaluated a method of delivering differential company health care based on the particular demands and needs of companies compared with the standard care in seven companies within an OHS. ${ }^{96}$ The approach was found to be feasible and a trend of increased satisfaction within the companies was noted. Fitko et al examined the cost effectiveness of the trend in the United States for corporations to switch from in house medical departments to outside contract organisations for OHSs. ${ }^{95}$ They found the cost for the same services of an in house department at a large oil refinery to be $42 \%$ less than that of outside providers (other benefits

Table 6 Summary of evaluation of occupational health service or occupational health service instruments

\begin{tabular}{|c|c|c|c|c|}
\hline & Input & Process & Output & Outcome \\
\hline Occupational health service in general & 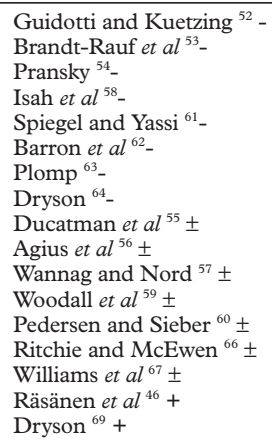 & & & $\begin{array}{l}\text { Husman et al }{ }^{91}- \\
\text { Wood et al }{ }^{90} \pm \\
\text { Draaisma et al }{ }^{93} \pm \\
\text { Rogers et al }{ }^{94}+ \\
\text { Fitko et al }{ }^{95}+ \\
\text { Weel and Slotboom }{ }^{96}+ \\
\text { Pachman et al }{ }^{97}+\end{array}$ \\
\hline Occupational health consultation & $\begin{array}{l}\text { Plomp }{ }^{65}- \\
\text { Plomp }{ }^{70}-\end{array}$ & Agius et al ${ }^{74}-$ & & \\
\hline Occupational rehabilitation & $\begin{array}{l}\text { Williams et al } l^{67}- \\
\text { Agius et al }{ }^{68}- \\
\text { Plomp }{ }^{70} \pm\end{array}$ & & Agius et $a l^{68}+$ & \\
\hline Pre-employment examination & & $\begin{array}{l}\text { Braddick et } \mathrm{al}^{75}- \\
\text { Evans and } \mathrm{Aw}^{76}- \\
\text { De Kort } \text { et }^{7 l^{77}}- \\
\text { Whitaker and Aw }{ }^{78} \pm \\
\text { De Zotti } \text { et al }{ }^{79}+ \\
\text { Milcovic and Macan }{ }^{80}+\end{array}$ & De Kort et $a l^{85}$ & Lowenthal ${ }^{98}$ - \\
\hline Periodic occupational health examination/surveillance & & $\begin{array}{l}\text { Udasin et al }{ }^{81}- \\
\text { Conway et al } \\
\text { Sugita } \text { et al }{ }^{71}+ \\
\text { Broersen } \text { et al }{ }^{84}+\end{array}$ & $\begin{array}{l}\text { Hessel and Zeiss }{ }^{86}{ }_{-} \\
\text {Rose and Bengtsson }{ }^{87}\end{array}$ & $\begin{array}{l}\text { Conway et al }{ }^{99} \pm \\
\text { Ren } \text { et al }{ }^{100} \pm \\
\text { Sugita } \text { et al }{ }^{71}+ \\
\text { Broersen } \text { et al }{ }^{84}+\end{array}$ \\
\hline Workplace investigation or evaluation of hazards & $\begin{array}{l}\text { Hulshof et al }{ }^{50}- \\
\text { Dryson }{ }^{69}+\end{array}$ & $\begin{array}{l}\text { Behrens and } \text { Müller }^{72} \text { - } \\
\text { Menckel }^{73} \text { - }\end{array}$ & $\begin{array}{l}\text { Mattila }{ }^{88}+ \\
\text { Peretz } \text { et al }{ }^{89}+\end{array}$ & Kahan et al ${ }^{101}+$ \\
\hline Occupational health education & Hulshof et al- & $\begin{array}{l}\text { Husman et al } l^{91}+ \\
\text { Porru et } a l^{102}+\end{array}$ & & Porru et al ${ }^{102}+$ \\
\hline
\end{tabular}


not included) and therefore recommend corporations to perform similar analyses before a decision is made to switch from inside to outside OHSs, at least if a desire to reduce expenses is the objective. As well as this, Pachman et al assessed the hidden saving in costs of an on site medical centre in a large company; in particular absenteeism was found it to be substantial. ${ }^{97}$ The cost effectiveness of preemployment examination was also questioned. Lowenthal examined in a retrospective analysis of records in a group of healthcare workers, the outcome of a non-specific comprehensive preplacement health evaluation compared with a minimal evaluation by a nurse. ${ }^{98}$ No difference in duration of employment, reason for ending work, workers' compensation claims, and use of healthcare resources in a period of 2-4 years after the examination was found. He concluded that comprehensive pre-employment examination is not a cost effective activity. In a large nationwide survey in the United States, the Occupational Safety and Health Administration (OSHA) investigated the prevalence, purposes, and effects or benefits from (periodic) occupational medical surveillance programmes. Conway et al reported that most responders with an existing programme did not detect a change in outcome variables like illnesses or insurance costs as a consequence of the programme. ${ }^{99}$ Most of the responders had, however, no procedure for evaluating the effectiveness of their medical surveillance programme. In the same journal issue, however, this OSHA study was severely criticised because of the lack of a clear definition of occupational medical surveillance, leading to misinterpretation by responders. ${ }^{103}$ To test the statement that periodic health examination leads to an increase in use or costs of health care (in our opinion not a negative outcome measure in itself), Ren et al analysed rates of use of healthcare services and insurance claims of a large group of local government employees during a 6 year period after introduction of a comprehensive periodic health examination programme. ${ }^{100}$ Confirmation of increasing costs and use was found, especially as a short term effect, but the authors themselves discussed distinct limitations of the study-for example, the lack of an adequate control group.

An evaluation study of an employee health education programme was conducted by Porru et al. ${ }^{102}$ The effects of health education in workers exposed to lead were examined before, 4 months after, and 1 year after the education programme was given by the OHSs in seven small factories. A highly significant improvement in knowledge of workers about lead poisoning and its prevention and also a decrease of $\mathrm{PbB}$ concentrations was found. Because during the study period no hygiene improvements or engineering changes were undertaken, the reduction of $\mathrm{PbB}$ seemed to be due to a change in hygienic behaviour. The authors therefore concluded that this OHS health education programme was effective.

\section{Discussion}

It is widely recognised that health services research and evaluation in OHSs should be placed high on the agenda of both researchers and practitioners in occupational health. In a Delphi study among 150 experts from OHSs, scientific research institutes, governmental and other administrative bodies, and companies in the Netherlands, design, implementation, and evaluation of control measures was ranked highest in the priority topics for research in the field of occupational health and safety. ${ }^{104}$ Considering the size of the field of occupational health care, the social and economical magnitude of occupational health problems, and the growing awareness and position of health services research, the number of studies on evaluation of OHSs or OHS activities that met the (not very restrictive) inclusion criteria is remarkably limited. Moreover, the nature of many of the 52 studies included in this review is more descriptive than really evaluative. Probably, many evaluation studies remain unpublished. Cherry refers to the often prevailing lack of interest of funders of intervention programmes in evaluating effectiveness of OHSs, and the rigor of the scientific community rejecting every other approach than randomised controlled trials. ${ }^{105}$

Our classification of the studies in input, process, output, and outcome may be arbitrary. A sharp border between process and outcome indicators does not always exist and some studies deal with different aspects. Input, process, and outcome are not characteristics or variables of quality but they offer a suitable approach for gaining information in the presence or absence of indicators of quality. ${ }^{23}$ For us, in this field with heterogeneous study objectives, it helped to categorise the evaluation studies.

In general, the methodological quality of most of the reviewed studies is not high. Robust study designs were only occasionally used. Most of the studies did not have an active intervention or a quasi-experimental design, did not use control groups, and did not define standards or criteria against which the study object was evaluated. Of course, this in itself does not necessarily disqualify these studies. Also qualitative research designs and case studies may be of value in studying aspects of occupational health care as provided by OHSs. Evaluation of OHSs can (and has to) be performed at different levels. Moreover, we have considered already the fact that in evaluation of health care in daily practice, the applicability of rigorous (intervention) study designs, for different reasons, is not always possible and researchers are forced to make compromises.

When looking at the results of this literature review (table 6 summarises the findings of this review) a differentiated picture of the evidence of effectiveness of OHSs arises. The OHSs or OHS programmes in general are studied from the input perspective: how many occupational physicians work in OHSs? The drawback of these studies and the reason for the many indefinite results is that they usually remain at 
the descriptive level. No criteria are used to assess the quality of the input. So, the questions such as "is the number of physicians sufficient to provide adequate care", and "are all branches of industry provided with adequate services" usually cannot be answered. Outcome, studied as satisfaction with OHSs in general, shows a slightly positive picture. Despite this satisfaction, input in OHSs is in most studies considered to be inadequate. Evaluation of the effectiveness of OHS activities and implementation of adequate measures may change this lack of adequate input.

It is striking to see that occupational health consultations and occupational rehabilitation are hardly studied. In sharp contrast with the extensive time spent on consultation by occupational physicians in most countries, the process remains more or less a "black box" and its outcome is hardly known. Moreover, the few studies that are conducted on this tend to be negative on input and process quality.

By contrast, the pre-employment examination has been well studied. Most of the studies give a negative result on process quality as well as on outcome. Only in specific circumstances may the pre-employment examination be useful-such as for the prevention of occupational asthma in certain occupational groups. ${ }^{79}$ However, even in this specific disorder, this can be questioned. In 1982, Cockroft et al concluded from a study among laboratory animal workers that pre-employment allergy screening would not substantially reduce the problem of occupational allergy in this group. ${ }^{106}$ More recently, de Kort and van Dijk made a calculation based on the validity characteristics of the tests to be used and the available epidemiological data on risk factors relative to the adverse outcome to be prevented, and estimated the effectiveness of pre-employment examination for this disorder to be low. ${ }^{107}$ This increasing amount of evidence of lack of effectiveness and efficiency of the pre-employment examination should lead to its general abandonment as a means of selecting personnel by OHSs.

Also, some positive findings emerge from this review. There is some evidence that periodic health monitoring or surveillance, especially when directed to specific occupational exposures, can be carried out with reasonable process quality. Whether this leads to a favourable outcome cannot be inferred from the studies included in this review. In a small scale evaluation of a periodic occupational health examination programme of one OHS in The Netherlands, most of the participating employees were positive about the process quality of the programme, but only $20 \%$ noticed a clear improvement in working conditions as a positive result of the programme. ${ }^{108}$ Although based on only a few studies, positive results were reported on process and outcome of education on occupational health hazards. ${ }^{91} 92102$ The identification and evaluation of occupational health hazards by a workplace survey can be done with a perceived high output quality, which, however, does not guarantee a favourable outcome.
RECOMMENDATIONS

There is still much left to be studied more thoroughly in studies that evaluate OHSs. In research programmes, much more effort should be directed at the scientific evaluation of the occupational health consultation and rehabilitation activities of occupational physicians. In this field it is important to use or develop an explicit theoretical basis for such studies. A clear theory on which activity or intervention could work best can help researchers design studies that provide more interpretable and generalisable results. These activities lend themselves quite well to rigorous study designs of methods - such as the randomised controlled trial. A recent example of such a trial is the study by van der Weide et al on the quality of occupational rehabilitation by occupational physicians for low back pain. ${ }^{109}$ Studying outcome and process quality of the consultation and rehabilitation activities could give clues for immediate improvement. However, this type of study requires the construction and implementation of professional guidelines with which the usual input and process can be compared. To date we know of few professional guidelines for and process evaluation of OHS activities.

In OHSs activities directed to groups-for example, an educational programmerandomisation at an individual level is not possible. This problem may be solved with a quasi-experimental approach and assigning plants or departments to an experimental and a control group of OHSs. We have recently used this design in evaluating an OHSs prevention programme on the effects of whole body vibration. ${ }^{110}$

Much work still remains to be done. More research is needed on demands and needs, policy and practice development, aspects of input, process and output (and their interrelations), and efficacy and effectiveness of OHSs in terms of benefits and harms of interventions. A theoretical framework for evaluation of OHSs should be discussed and further developed, in particular on occupational medical consultation and rehabilitation. Researchers and practitioners should collaborate to work on appropriate ways to monitor and evaluate performance and quality of OHSs in practice. The use of OHS databases for evaluation of effect should be encouraged, and easily measurable outcome measures are needed for small scale evaluation by OHSs themselves. There is a need for new and better performance indicators. ${ }^{111}$ In another paper, we have described the development and evaluation of a quality assessment instrument for occupational physicians. ${ }^{12}$ Such methods can be used for both single evaluations and for a continuing process of improving occupational health care. In the quest for evidence-based occupational health care more and better research on effectiveness of OHSs is needed but also nonexperimental activities - such as quality assurance or guideline implementation - should be guided by scientific principles. Researchers must be encouraged to publish the results internationally. Occupational medical journals 
should consider measures to facilitate publications on this topic.

1 World Health Organisation. Global strategy on occupational health for all. Recommendation of the 2 nd meeting of the WHO Collaborating Centres in Occupational Health. Beijing, China 11-14 October 1994. Geneva: WHO, 1995:95.

2 International Commission on Occupational Health. Policy Document of the Scientific Committee on Health Services
Research and Evaluation in Occupational Health. Amsterdam: ICOH, 1993.

3 Pope C, Mays N. Opening the black box: an encounter in the corridors of health services research. BMF 1993;306 315-8.

4 Epstein AM. The outcomes movement-will it get us where we want to go? $N$ Engl 7 Med 1990;323:266-70

5 Wannag A. Classification system for work in occupational health services. Work content of Norwegian occupational physicians. Scand $\mathcal{F}$ Work Environ Health 1993;19:390-3.

6 National Institute for Occupational Safety and Health (NIOSH). National research agenda. Washington: NIOSH, DHHS, 1996. (Publ No 96-115.)

7 Behrens J, Westerholm P, Baranski B. Introduction: the new occupational health and evaluation research as its pathbreaker. In: Behrens J, Westerholm P, eds. Occupational health policy, practice and evaluation. Bremen: WHO EUR/ICP/EPOL, 1996

8 Pransky G, Himmelstein J. Outcomes research: implications for occupational health. Am F Ind Med 1996;29:573-83

9 Husman K. Principles and pitfalls in health services research in occupational health systems. Occup Med 1993; research in occupation 1):10-14.

10 Van Dijk FJH, de Kort W, Verbeek JHAM. Quality assessment of occupational health care instruments. Occup Med 1993;43(suppl 1):28-33.

11 World Health Organization. Evaluation of occupational health and industrial hygiene services. Report on a WHO Working Group. Copenhagen: WHO, 1982. (Euro Reports and Studies 56.)

12 Schulte PA, Goldenhar LM, Connally LB. Intervention research: science, skills, and strategies. Am F Ind Med 1996; 29:285-8.

13 Skov T, Kristensen TS. Etiologic and prevention effectiveness intervention stu

14 Goldenhar LM, Schulte PA. Intervention research in occupational health and safety. 7 Occup Med 1994;36:763-75.

15 Van der Weide WE, Verbeek JHAM, Tulder MW van. Vocational outcome of interventions for low-back pain. Scand $\mathcal{f}$ tional outcome of interventions for lo

16 Warner KE, Wickizer TM, Wolfe RA, et al. Economic implications of workplace health promotion programs: a review of the literature. F Occup Med 1988;30:106-12.

17 Pelletier K. A review and analysis of the health and cost-effective outcome studies of comprehensive health promotion and disease prevention. American fournal of Health Promotion 1991;5:311-5.

18 Pelletier K. A review and analysis of the health and cost-effective outcome studies of comprehensive health promotion and disease prevention programs at the worksite: 1991-3 update. Am f Health Promot 1993;8:5062.

19 Black N. Why we need observational studies to evaluate the effectiveness of health care. BMF 1996;312:1215-8.

20 Rossi PH, Freeman HE. Evaluation, a systematic approach, 3rd ed. Beverly Hills: Sage, 1985

21 Oxman AD, ed. Section VI: Preparing and maintaining systematic reviews. Cochrane Collaboration handbook. Oxford: Cochrane Collaboration, 1994.

22 Holland WW, ed. Evaluation of health care. Oxford: Oxford University Press, 1983.

23 Donabedian A. The quality of care. How can it be assessed? FAMA 1988;260:1743-8.

24 Taylor Fitz-Gibbon C, Lyons Morris L. How to design a program evaluation. Newbury Park: Sage, 1987

25 Campbell DT, Stanley JC. Experimental and quasiexperimental designs for research. Reprinted from handbook of research on teaching. Boston: Houghton Mifflin, 1963.

26 Cook TD, Campbell DT. Quasi-experimentation. Design and analysis issues for field settings. Boston: Houghton Mifflin, 1979.

27 Guidotti TL, Cowell JWF, Jamieson GG, et al. Program evaluation. In: American Medical Association. Occupational evaluation. In: American Medical Association. Occupational

28 Draaisma D. A conceptual approach for the evaluation of the quality and effectiveness of occupational health care. In: Rantanen J, Lehtinen S, eds. New trends and developments in occupational health services. Amsterdam: Elsevier, 1991.

29 Van Dongen M. Evaluatie van GVO-interventies (Evaluation of health education interventions). In: Damoiseaux V van der Molen HT, Kok GJ. Gezondheidsvoorlichting en gedragsverandering (Health education and behavioral change). Assen, The Netherlands: van Gorcum, 1993.

30 Bloom BS. Does it work? The outcomes of medical interventions. Int $\mathcal{F}$ Technol Assess Health Care 1990;6:32632.

31 Long RJ, Wilkinson WE. A theoretical framework for occupational health program evaluation. Occupational Health Nursing 1984:257-9.

32 Rubenstein LZ, Aronow HU, Schloe M, et al. A home-based geriatric assessment, follow-up and health promotion program: design, methods, amd baseline findings from a -year randomized clinical trial. Aging Clin Exp Res 1994;6: $105-20$

33 Davies HTO, Crombie IK. Assessing the quality of care. Measuring well supported processes may be more enlightening than monitoring outcomes. BMF 1995;311:766.

34 Cohen HH, Jensen RC. Measuring the effectiveness of an industrial truck safety training program. F Safety Res 1984; 15:125-35.

35 Brook RH, McGlynn EA, Cleary PD. Quality of health care. Part 2: measuring quality of care. $N$ Engl f Med 1996;335: 966-70.

36 Tijssen IMJG, Elsinga E. Evaluatie-onderzoek op het terrein van de gezondheidszorg (Evaluation research in the field of medicine). In: Maarse JAM, Mur-Veeman (eds). Beleid en beheer in de gezondheidszorg (Policy and management in health care). Assen, The Netherlands: van Gorcum, 1990.

37 Welch CE, Grover PL. An overview of quality assurance. Medical Care 1991;29(suppl):AS8-28.

38 Macdonald EB, Agius RM, McCloy EC, et al, eds. Quality and audit in occupational health. London: Faculty of Occupational Medicine of the Royal College of Physicians of London, 1995

39 Klazinga N. Compliance with practice guidelines: clinical autonomy revisited. Health Policy 1994;28:51-66.

40 Grimshaw JM, Russell IT. Effect of clinical guidelines on medical practice: a systematic review of rigorous evaluations. Lancet 1993;342:1317-22.

41 Grilli R, Lomas J. Evaluating the message: the relationship between compliance rate and the subject of a practice guideline. Medical Care 1994;32:202-13.

42 American Public Health Association (APHA) technical report. Criteria for the development of health promotion and education programs. Am f Public Health 1987;77:8992

43 Karvonen M. Epidemiology in the context of occupational health. In: Karvonen M, Mikheev MI, eds. Epidemiology of occupational health. Copenhagen: WHO Regional Publications, 1986. (European Series No 20.)

44 Stonecipher LJ, Hyner GC. Health practices before and after a work-site health screening. Differences among subpopulations of employees. F Occup Med 1993;35:297-306.

45 Conrad P. Worksite health promotion: the social context. Soc Sci Med 1988;26:485-9.

46 Räsanen K, Notkola V, Kankaanpää E, et al. Role of the occupational health services as a part of illness-related pri-
mary care in Finland. Occup Med 1993;43(suppl 1):23-7.

47 Menckel E. Evaluating and promoting change in occupational health services - models and applications. Stockholm: The Swealth services - models and applications.

48 Cho KS, Park H, Lee SH, et al. Evaluation of occupational health service systems. Seoul: Catholic Industrial Medical Center/Catholic University Medical College, 1992. (Center File 3-P-89-0326, Final technical report.)

49 Parillo VL. Systems analysis of an occupational health department. Recommendations to increase effectiveness. American Association of Occupational Health Nurses fournal 1993;41:220-7.

50 Hulshof CTJ, Verbeek JHAM, van Dijk FJH. Development and evaluation of an occupational health services programme on the prevention and control of effects of vibration. Occup Med 1993;43(suppl 1):38-42.

51 Verbeek JHAM, van der Weide WE, Hulshof CTJ. Ervaringen met kwaliteitsonderzoek en kwaliteitszorg in de Nederlandse bedrijfsgezondheidszorg (Experiences with quality assessment and quality assurance in the Dutch occupational health care). Problemen van Arbeidsgeneeskunde (Problems in occupational medicine). Leuven, Belgium: Afd lems in occupational medicine). Leuven, Belgium: Afd 31:99-109.

52 Guidotti TL, Kuetzing BH. Competition and despecialization: an analytical study of occupational health services in San Diego, 1974-84. Am F Ind Med 1985;8: $155-65$.

53 Brandt-Rauf PW, Teichman RF. Current and future needs for occupational medicine physicians in non-industrial settings: a survey of multispecialty group medical practices and health maintenance organizations. F Occup Med 1988; 30:928-33.

54 Pransky G. Occupational medicine specialists in the United States: a survey. F Occup Med 1990;32:985-8.

55 Ducatman AM, Forman S, Teichman R, et al. Occupational physician staffing in large US corporations. 7 Occup Med 1991;33:613-8.

56 Agius RM, Lee RJ, Murdoch RM, et al. Occupational physicians and their work; prospects for audit. Occup Med 1993; 43:159-63.

57 Wannag A, Nord E. Work content of Norwegian occupational physicians. Scand $\mathcal{F}$ Work Environ Health 1993;19: 394-8.

58 Isah C, Asuzu MC, Okojie OH. Occupational health services in manufacturing industries in Nigeria. Occup Med 1996;46:333-6.

59 Woodall GE, Higgins CW, Dunn JD, et al. Characteristics of the frequent visitor to the industrial medical department and implications for health promotion. F Occup Med 1987 29:660-4

60 Pedersen DH, Sieber WK. Some trends in worker access to health care in the United States (1974-83). Am f Ind Med 1989;15:151-65.

61 Spiegel J, Yassi A. Community health centre-based occupaional health services for the small workplace: an Ontario study of employer acceptability. Can f Public Health 1989; 80:355-8. 
62 Barron P, Steyn SD, Malekela LL, et al. Occupational health services in Johannesburg and Randburg. South Afr Med $\mathscr{F}$ services in Johan

63 Plomp HN. Workers' attitude towards the occupational physician. f Occup Med 1992;34:893-901.

64 Dryson E. Occupational health needs in small industry in New Zealand: preferred sources of information. Occup Med 1993;43:176-9.

65 Plomp HN. Employees' and occupational physicians' different perceptions of the work-relatedness of health problems: a critical point in an effective consultation process. Occup Med 1993;43(suppl 1):18-22.

66 Ritchie KA, McEwen J. Employee perceptions of workplace health and safety issues. Can a questionnaire contribute to health needs assessment? Occup Med 1994;44:77-82.

67 Williams N, Sobti A, Aw TC. Comparison of perceived occupational health needs among managers, employee representatives and occupational physicians. Occup Med 1994; 44:205-8.

68 Agius RM, Seaton A, Lee RJ. Audit of sickness absence and fitness-for-work referrals. Occup Med 1995;45:125-30.

69 Dryson E. Preferred components of an occupational health service for small industry in New Zealand: health protection or health promotion? Occup Med 1995;45:31-4.

70 Plomp HN. Accessibility and utilization of occupational health services. Scand $\mathcal{F}$ Work Environ Health 1996;22:21622.

71 Sugita M, Harada A, Taniguchi M, et al. Quality control program on biological monitoring by Japan Federation of occupational health organizations. Int Arch Environ Health 1991;62:569-77.

72 Behrens J, Müller R. Supply and demand factors in occupational health; determinants of self-reported compliance with the work place related requirements of the German Work Safety Law. Occup Med 1993;43(suppl 1):47-9.

73 Menckel E. Accident prevention by safety engineers within occupational health services in Sweden. Safety Sci 1993;16: 465-84.

74 Agius RM, Lee RJ, Symington IS, et al. An audit of occupational medicine consultation records. Occup Med 1994;44: 151-7.

75 Braddick MR, Atwell CP, Aw T-C. Audit of preemployment health assessment in the National Health Service. Occup Med 1992;42:36-8.

76 Evans G, Aw TC. Should prospective NHS employees have routine blood counts? Occup Med 1992;42:79-82.

77 Kort WLAM de, Post Uiterweer HW, van Dijk FJH. Agreement on medical fitness for a job. Scand $\mathcal{F}$ Work Environ Health 1992;18:246-51.

78 Whitaker S, Aw TC. Audit of pre-employment assessments by occupational health departments in the National Health Service. Occup Med 1995; 45:75-80.

79 De Zotti R, Molinari S, Larese F, et al. Pre-employment screening among trainee bakers. Occup Environ Med 1995; 52:279-83.

80 Milkovic-Kraus S, Macan J. Can pre-employment patch testing help to prevent occupational contact allergy? testing help to prevent occupa

81 Udasin IG, Buckler G, Gochfeld M. Quality assurance audits of medical surveillance programs for hazardous audits of medical surveillance programs fo
waste workers. F Occup Med 1991;33:1170-4.

82 Conway H, Simmons J, Talbert T. The Occupational Safety and Health Administration's 1990-1 survey of occupational medical surveillance prevalence and type of curren practices. F Occup Med 1993;35:659-69.

83 Conway H, Simmons J, Talbert T. The purposes of occupational medical surveillance in US industry and related health findings. F Occup Med 1993;35:670-86

84 Broersen JPJ, Weel ANH, van Dijk FJH, et al. The atlas of health and working conditions by occupation 2 . A comparison with the "Atlas of health and working conditions in the construction industry". Int Arch Occup Environ Health 1995;67:337-42.

85 Kort WLAM de, Fransman LG, van Dijk FJH. Preemployment medical examinations in a large occupational health service. Scand f Work Environ Health 1991;17:392-7.

86 Hessel PA, Zeiss E. Evaluation of the periodic examination in the South Africa mining industry. F Occup Med 1988;30: $580-6$

87 Rose G, Bengtsson C. Evaluation of a laboratory health examination programme in a Swedish industry (Volvo). Scand F Clin Lab Invest 1991;51:155-60.

88 Mattila M. Improvement in the occupational health program in a Finnish construction company by means of systematic workplace investigation of job load and hazard analysis. Am F Ind Med 1989;15:61-72.

89 Peretz C, Goldberg Ph, Derazne E, et al. Assessment of the extent of implementation of the recommendations made in occupational hygiene survey reports. Ann Occup Hyg 1992; 36:229-38.

90 Wood JM, Kelman R, Pilkington W, et al. Comparative perceptions of the delivery of occupational health services in industry. Fournal of Occupational Health and SafetyAustralia and New Zealand 1987;3:632-8.

91 Husman K, Notkola V, Virolainen R, et al. Farmers' occupational health program in Finland 1979-88: from research to practice. Am F Ind Med 1990;18:379-84.

92 Notkola V, Husman K, Tupi K, et al. Farmers' occupational health programme in Finland, 1979-87. Soc Sci Med 1990; 30:1035-40.

93 Draaisma D, Dam J, Winter CR de. Quality and effectiveness of occupational health services evaluated by the providers. Occup Med 1993;43(suppl 1):50-5.

94 Rogers B, Winslow B, Higgins S. Employee satisfaction with occupational health services. Results of a survey. American Association of Occupational Health Nurses fournal 1993;41: $58-65$.

95 Fitko J, Kalina CM, Fisher AM, et al. A cost-effectiveness analysis of an in-house corporate occupational medical department. F Occup Med 1994;36:161-5.

96 Weel ANH, Slotboom MAJ. Quality improvement by means of differential occupational health care: an experiment in a regional occupational health centre. Occup Med 1996;46: $20-4$.

97 Pachman JS, Stempien DE, Milles SS, et al. The hidden savings of an on-site corporate medical center. $f$ Occup Environ Med 1996;38:1047-8.

98 Lowenthal G. Medical center worker preplacement screening: a follow-up study. F Occup Med 1986;28:451-2.

99 Conway H, Simmons J, Talbert T. Effects of occupational medical surveillance programs as perceived by respondents to the Occupational Safety and Health Administration. 7 Occup Med 1993;35:687-97.

100 Ren A, Okubo T, Takahashi K. Comprehensive periodic health examination: impact on health care utilisation and costs in a working population. F Epidemiol Community Health 1994;48:476-81.

101 Kahan E, Peretz C, Rybski M, et al. Determination of consumer satisfaction: a basic step for quality improvement of an occupational hygiene service. Occup Med 1995;45:193-8.

102 Porru J, Donato F, Apostoli P, et al. The utility of health education among lead workers: the experience of one program. Am f Ind Med 1993;22:473-81.

103 Hathaway JA. Medical surveillance: extent and effectiveness? F Occup Med 1993;35:698-700.

104 Van der Beek AJ, Frings-Dresen MHW, van Dijk FJH, et al. Priorities in occupational health research: a Delphi study in The Netherlands. Occup Environ Med 1997;54:504-10.

105 Cherry N. Evaluation of preventive measures. In: McDonald C. Epidemiology of work related diseases. London: BMJ Publishing Group, 1995

106 Cockroft A, Edwards J, McCarthy P. The role of pre-employment allergy screening in animal workers. Eur $\mathcal{f}$ Respir Dis 1982;62:42-3.

107 Kort W de, van Dijk F. Preventive effectiveness of pre-employment medical assessments. Occup Environ Med 1997;54:1-6.

108 Hulshof C, Remijn B, Leonhard N. Het periodiek bedrijfsgezondheidkundig onderzoek (PBGO), ervaringen van deelnemers (Periodic Occupational Health Survey, experiences of participants). T Soc Gezondheidsz 1990;68:397403. (In Dutch, English abstract.)

109 van der Weide WE, Verbeek JHAM, van Dijk FJH. A randomised trial of occupational rehabilitation for low-back pain. Efficacy on pain, functional disability, general health and sick leave. In: Weide WE van der. Quality of occupational rehabilitation for low-back pain [academic hesis]. Amsterdam: University of Amsterdam, 1998:8599.

110 Hulshof CTJ, Braam ITJ, Verbeek JHAM, et al. Evaluation of an occupational health prevention program on wholebody vibration in forklift truck drivers. In: Hulshof CTJ. Prevention and control of adverse effects of whole-body vibration, an evaluation study in occupational health services [academic thesis]. Amsterdam: University of Amsterdam, 1998:153-79.

111 Emmett EA. What is the strategic value of occupational and environmental medicine? $\mathcal{f}$ Occup Environ Med 996;38:1124-34.

112 Van der Weide WE, Verbeek JHAM, van Dijk FJH, et al. Development and evaluation of a quality assessment instrument for occupational physicians. Occup Environ Med 1998;55:375-82. 